\title{
THE ROLE OF HUMAN PAPILLOMAVIRUS INFECTION IN THE HEAD AND NECK REGION AND METHODS FOR ITS DETECTION
}

\author{
Katarzyna Bogusiak ${ }^{1}$, Józef Kobos ${ }^{2}$
}

${ }^{1}$ Clinical Department of Maxillofacial Surgery, Medical University of Lodz, Lodz, Poland

${ }^{2}$ Department of Pathomorphology of the Age of Development, Medical University of Lodz, Lodz, Poland

\begin{abstract}
Human papillomaviruses (HPV) are the etiological factors of many benign and malignant lesions localized in the skin and mucous membranes in the region of the urogenital organs and head and neck.

Currently, most assays for the detection of HPV are based on detecting the presence of viral nucleic acids, mostly viral DNA. These molecular techniques can be divided into: 1) methods based on a targeted, selective amplification of nucleic acids, 2) signal amplification methods, 3) nucleic acid hybridization assays.

This paper presents and explains a number of different HPV detection methods and provides examples of some commonly available commercial tests.
\end{abstract}

Key words: human papillomavirus, HPV, detection methods, head and neck cancer.

More than 150 types of human papillomavirus (HPV) are known. In the oral cavity, there are over twelve types, the most common being HPV 2, 4, 6, $11,13,16,18,30,32[1,2]$. Human papillomavirus infection in the oral cavity may lead to the development of three types of viral infections - clinical, subclinical, and latent infection - depending on the possibility to detect it. Overt infection leads to formation of macroscopic changes in the mucous membrane, accompanied by characteristic microscopic image of the affected tissue. Subclinical infection is characterized by the absence of macroscopic changes and subjective symptoms, while HPV infection can be confirmed on the basis of colposcopic, cytological, histological and molecular examinations [3]. Latent infection is, according to some authors, the most common form of infection, when clinical symptoms are absent and the diagnosis cannot be confirmed by histopathology or cytology [3, 4]. Such HPV infection does not cause morphological changes in the affected epithelium. Diagnosis of latent infection can only be established based on the positive results of molecular virological tests [4]. During latent infection the HPV replication cycle and its complete reproduction does not occur, because the amount of viral DNA in the infected tissues is small and it is found mainly in the parabasal layer of the epithelium [3].

Infection with human papilloma virus can lead to a variety of changes in the mucosa, manifesting with different symptoms. Human papillomavirus is responsible for the formation of non-neoplastic changes, precancerous lesions. It is also detected in pathologically intact mucosa [5]. The frequency of HPV detection in normal-looking mucous membrane varies from 0 to $55 \%[4,6]$. This discrepancy may result from differences in methodology used for virus detection, site and method of sample collection, as well as from geopolitical differences in study groups and other environmental factors. Human papillomavirus is also detected in malignant tumors of the oral mucosa, and according to some authors it can play an important role in carcinogenesis $[6,7]$. Table I shows the relationship between pathological lesions of head and neck, and various types of HPV.

High-risk (HR) HPV was proved to be an important factor in the development of head and neck squamous cell carcinoma (HNSCC), and cancers of the oral cavity and oropharynx in particular (Fig. 1). 
Table I. Pathological lesions of the head and neck caused by HPV

\begin{tabular}{|c|c|c|c|}
\hline & MuCosal Lesions & HPV TYPES & FREQUENCY \\
\hline $\begin{array}{l}\text { Chang et al. [23], Feller et al. [54], } \\
\text { Padayachee et al. [55] }\end{array}$ & $\begin{array}{l}\text { Verruca vulgaris } \\
\text { (common wart) }\end{array}$ & $1,2,4,6,7,11,16,57$ & $0.5-74 \%$ \\
\hline Eversole et al. [56], Tominaga et al. [57] & $\begin{array}{l}\text { Condylomata acuminate } \\
\text { (anogenital warts) }\end{array}$ & 6,11 & $13-85 \%$ \\
\hline Sand et al. [58], & Leukoplakia & $2,6,11,16,18$ & $0-80 \%$ \\
\hline \multicolumn{4}{|l|}{$\begin{array}{l}\text { Saghravanian et al. [59], Miller et al. [60], } \\
\text { Kashima et al. [61] }\end{array}$} \\
\hline $\begin{array}{l}\text { Chang et al. [23], Pfister et al. [62], } \\
\text { Padayachee et al. [63], Henke et al. [64], }\end{array}$ & Focal epithelial hyperplasia & $1,6,13,32$ & Up to $100 \%$ \\
\hline \multicolumn{4}{|l|}{ Jontell et al. [65] } \\
\hline $\begin{array}{l}\text { Silverman et al. [66], Manjarrez et al. [67], } \\
\text { Aaltonen et al. [68] }\end{array}$ & Respiratory papilloma & $6,11,30$ & $33-90 \%$ \\
\hline Piva et al. [69] & Squamous cell papilloma & 6,11 & Sporadically \\
\hline Syrjänen et al. [70] & $\begin{array}{l}\text { Solitary bronchial squa- } \\
\text { mous cell papilloma }\end{array}$ & $6,11,16,18$ & $39.1-53.4 \%$ \\
\hline $\begin{array}{l}\text { Syrjanen et al. [10], Hasegawa et al. [71], } \\
\text { Kraft et al. [72] }\end{array}$ & $\begin{array}{l}\text { Papilloma of the paranasal } \\
\text { sinuses }\end{array}$ & $11,13,32$ & $22-79 \%$ \\
\hline Hwang et al. [73] & Papillary carcinoma & $6,11,16,18$ & $58.8 \%$ \\
\hline & Squamous cell carcinoma & & \\
\hline Chuang et al. [74] & \multirow[t]{5}{*}{ Oral region } & 16 & $33.9 \%$ \\
\hline Elamin et al. [75] & & 6,16 & $50 \%$ \\
\hline Zhang et al. [6] & & 16,18 & $74 \%$ \\
\hline Premoli et al. [76], Ostwald et al. [77] & & $6,11,16,18$ & $60-62 \%$ \\
\hline Balaram et al. [78] & & $6,11,16,18$ & $\begin{array}{l}74 \% \\
41 \% \text { multiple } \\
\text { HPV infection }\end{array}$ \\
\hline $\begin{array}{l}\text { Mehanna et al. [79], } \\
\text { Hansson et al. [80] }\end{array}$ & Oropharynx region & 16,18 & $36-72 \%$ \\
\hline de Oliveira et al. [81], & Larynx region & 16,18 & $37.3 \%$ \\
\hline Baumann et al. [82], & & $16,26,31,39,52$ & $16 \%$ \\
\hline Morshed [83] & & 7,27 & $38.9 \%$ \\
\hline Bishop et al. [84] & Maxillofacial region & $16,18,31,32$ & $21-30 \%$ \\
\hline
\end{tabular}

The role of HPV in carcinogenesis in the head and neck region is analogous to its role in carcinogenesis in the genital region. The role of HPV 16 and 18 in carcinogenesis is associated primarily with the oncogenic activity of E6 and E7 proteins. Formation of complexes between viral proteins (E6 and E7) and tumor suppressor proteins leads to the loss of their function, loss of control of the cell cycle and uncontrolled cell proliferation [8]. The viral proteins function in the cell cycle control system by interacting with proteins $\mathrm{p} 16, \mathrm{p} 53$ and $\mathrm{Rb}$. This thesis is supported by the following arguments: the HPV virus tropism for epithelial cells and morphological similarity of the epithelium of the mouth and throat to urogenital epithelium, changes in the genome of human keratinocytes in in vitro studies, significantly (up to several times) higher presence of high-risk HPV DNA in premalignant conditions and squamous cell carcinoma of the head and neck in comparison with normal oral mucosa, the presence of the viral oncogenes E6 and E7 in tumor material, the need for expression of E6 and E7 proteins for sustaining neoplastic phenotype in tumor cell lines, and the interaction of viral proteins with oncogenic growth 


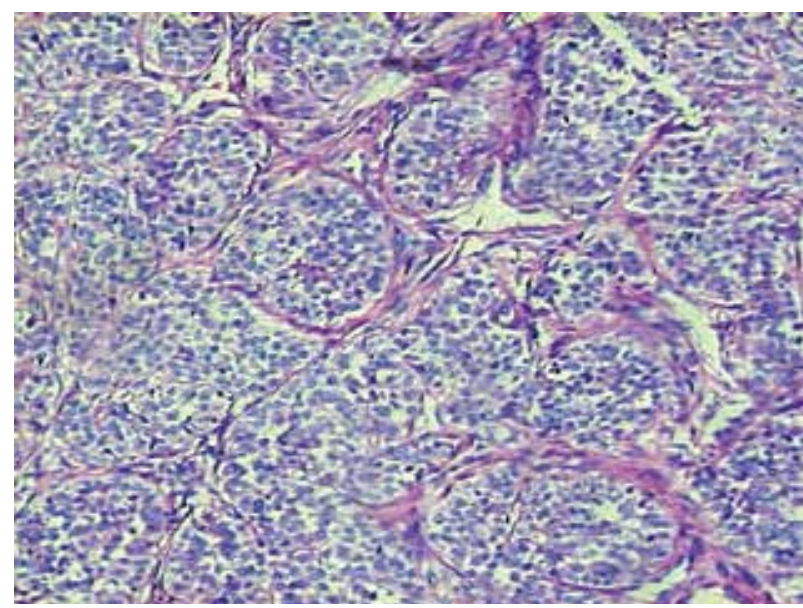

Fig. 1. HPV-related squamous carcinoma of the oropharynx HE, original magnification $100 \times$

factors of the host [9, 10]. A separate group of HNSCC has been defined, which includes HPV-related cancers characterized by different biology, gene expression profile, the frequency of P53 mutations and expression of p16. The biology of HPV-positive and HPV-negative tumors differs, among others, in p53 degradation (in HPV-positive cancers this protein is inactivated by E6 protein, in HPV-negative tumors by genetic mutation) and $\mathrm{pRB}$ pathway inactivation (by binding E7 oncoprotein and by cyclin D1 amplification, respectively) [11]. Moreover, expression of p16INK4A is highly correlated with human papillomavirus infection in head and neck squamous cell carcinoma, whilst HPV-negative tumors are characterized by a higher number of chromosomal alterations and amplifications, and are more frequently associated with P53 mutations $[12,13]$. Significance of p16 in Site-specific HPV Positive and HPV Negative Head and Neck Squamous Cell Carcinoma.

Some genes differentially expressed between HPVpositive and HPV-negative oropharyngeal cancer (e.g. TYMS, STMN1, CCND1, and RBBP4) are involved in chemotherapy or radiation sensitivity. The occurrence of HPV-related cancers is associated with:

1) significantly lower mean age of the patients,

2) significantly lower or no involvement of classical risk factors such as smoking and alcohol consumption,

3) a distinct factor describing this type of cancer is the history of sexual behaviors (higher number of partners and oral sex),

4) more aggressive metastasis to the lymphatic system of the neck,

5) better response to radio- and chemotherapy as compared with HPV-negative tumors,

6) better prognosis (less severe course and longer survival time),

7) low number of DNA mutations,

8) single small chromosomal aberrations,

9) long promotion (latency period) [15].

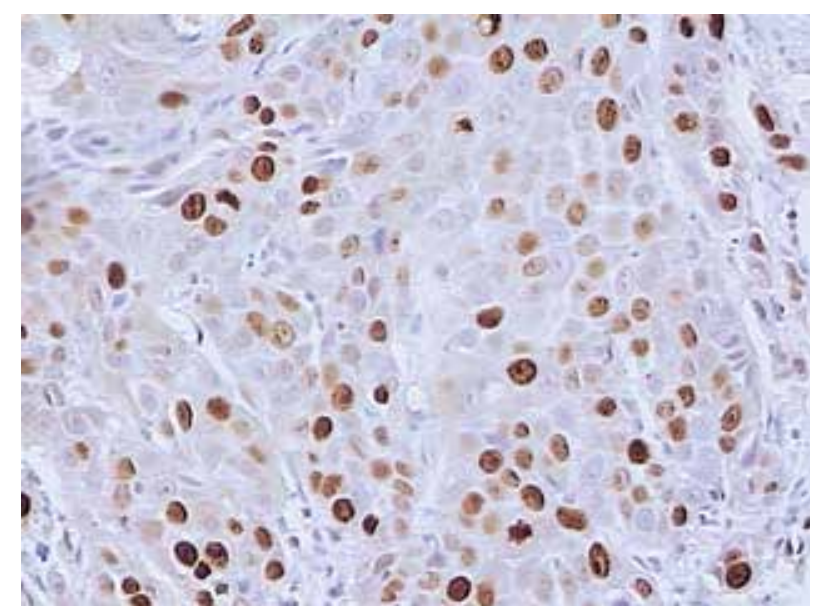

Fig. 2. HPV-related squamous carcinoma of the oropharynx Ki-67 staining, original magnification $200 \times$

Human papillomavirus-related cancers are characterized by fast growth, which is reflected in high Ki-67 proliferation index (Fig. 2). Despite the fast tumor growth and more aggressive metastasis to the lymphatic system, HPV-related cancer patients are believed to have a better 5-year survival rate. Many factors can contribute to better treatment outcome: younger age of patients, better health status and increased sensitivity to radio- and chemotherapy. On the other hand, Duray et al. observed that high risk HPV positivity was correlated with a poorer prognosis in terms of a decreased 5-year disease-free survival rate compared with HPV-negative tumors [16]. Some authors hypothesized that treatment outcome of HPV-related tumors can be affected by the anatomical region. Studies that proved that better overall outcome is associated with HPV infection included patients with tumors of the oropharyngeal and tonsillar region. Gillison believes that tumors of the oropharyngeal region may have an etiology distinct from tumors at nonoropharyngeal sites [17]. It was also proved that smoking deteriorates outcome in patients with HPV-positive cancers [16].

The role of low risk (LR) HPV in the development of HNSCC remains controversial. HPV 6 and 11 are risk factors for irradiation-induced malignant transformation of benign papillomas $[18,19]$.

\section{Human papillomavirus detection methods}

The detection of HPV is heavily influenced by: site of the specimen collection (in the oral cavity, tonsil crypts at the junction of squamous and cylindrical epithelium are most sensitive to HPV), collection method (scrapings, swabs, biopsy, sections), storage and preparation methods (frozen at $-80^{\circ} \mathrm{C}$, fresh samples, specimens stored in formalin and embedded in paraffin) [8]. The test method itself is also of utmost 


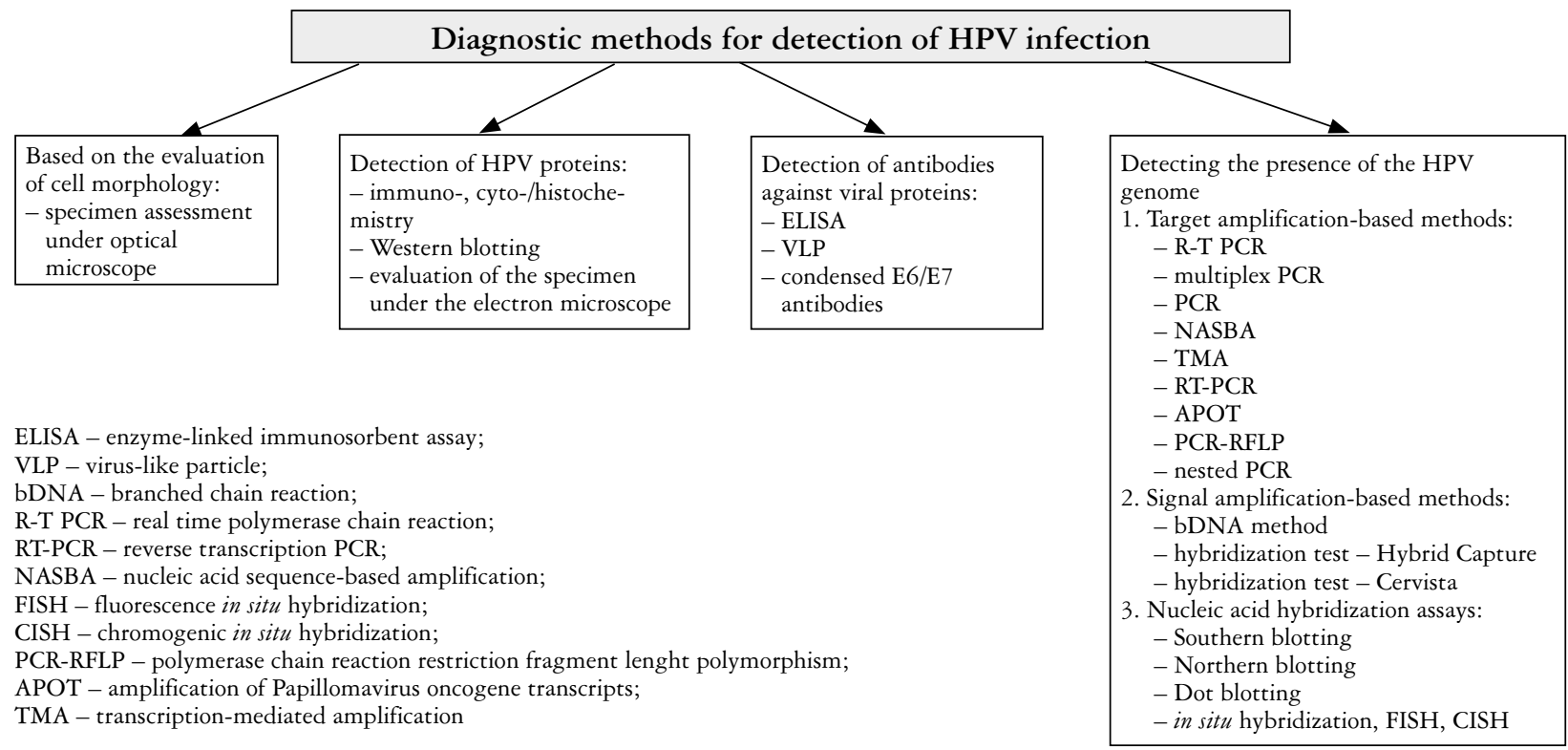

Fig. 3. Diagnostic methods for detection of HPV infection

importance. The techniques used for detecting HPV virus are shown in Fig. 3.

Diagnostic techniques differ in virus detection sensitivity, labor intensiveness, complexity of the procedure, and costs. Methods based on the evaluation of cell morphology detect viruses with low sensitivity. They also depend on the quality of the collected specimen and the laboratory staff experience. With their use virus type cannot be specified [20]. Techniques based on detection of viral proteins are also insensitive, as well as time-consuming and cumbersome. This results from the course of HPV infection - late proteins, such as viral capsid proteins, can be detected only in clinically overt infections, while early proteins are present only in small quantities. Moreover, the quality, sensitivity and specificity of antibodies against viral proteins are insufficient.

In order to detect late viral proteins, antibodies against the bovine papilloma virus (BPV) are used, due to their cross-reactivity with late HPV proteins. Detection of early proteins E6 and E7 is possible due to the existence of anti-E6 and anti-E7 antibodies, but is limited to research projects only [21].

Immunohistochemical methods also allow one to detect p16 and MCM 7 proteins with the use of specific antibodies [22]. During a clinically overt infection the virus particles are visible under an electron microscope [23]. Research studies on HPV virus detection demonstrated the presence of antibodies against viral proteins in immunoassay ELISA tests (enzyme-linked immunosorbent assay), as well as in tests using condensed E6/E7 viral proteins [21, 24]. Currently, however, there are no standardized methods for serological detection of HPV. Most of these methods are based on tests using virus-like particles
(VLPs), with the major capsid protein L1. Recently, a new serological test using both viral capsid proteins L1 and L2 for the detection of HPV 16 and 18 has been developed [25]. Nevertheless, the detection of HPV virus is now mainly based on molecular techniques, using the process of hybridization and detecting genetic material of the virus. They can be divided into three main categories: 1 ) methods based on targeted, selective amplification of nucleic acids, 2) methods based on the detection of signal amplification, 3) nucleic acid hybridization assays. These include both high-sensitivity methods of HPV infections detection, using the polymerase chain reaction (PCR), and methods of low sensitivity, which include methods using in situ hybridization (ISH). Their advantages and disadvantages are shown in Table II. Some of these methods are used for investigation of various biomarkers associated with HPV infection such as HPV-DNA viral load quantification and integration, and E6/E7 expression, that can be useful in prediction of progression of HPV-related lesions [26].

\section{Target amplification-based methods}

They are based on the PCR. Their application allows one to detect HPV, determine the amount of viral particles in the sample, sequence viral DNA and analyze mutations. They can also be configured to simultaneously monitor several different types of HPV using "multiplex PCR", where the reaction is carried out simultaneously with multiple pairs of primers specific for genes from different types of HPV. By using PCR-based methods it is possible to detect even a single copy of DNA per 10 cells [27]. 
Table II. Molecular methods for the detection of HPV

\begin{tabular}{|c|c|c|}
\hline $\begin{array}{c}\text { DiagNOSTIC } \\
\text { METHODS }\end{array}$ & ADVANTAGES & DiSADVANTAGES \\
\hline $\begin{array}{l}\text { Target } \\
\text { amplification } \\
\text { based methods }\end{array}$ & $\begin{array}{l}\text { - They allow one not only to assess the presence of the } \\
\text { HPV virus, but also to determine the type and severity } \\
\text { of the infection } \\
\text { - They allow the differentiation of infection, depending } \\
\text { on the type of virus } \\
\text { - Some methods allow the differentiation of episomal from } \\
\text { integrated DNA } \\
\text { - High sensitivity and specificity } \\
\text { - Highly automated assays } \\
\text { - They allow simultaneous amplification of many frag- } \\
\text { ments of genetic material (multiplex PCR) and differenti- } \\
\text { ation of multiple amplicons (multiplex, real-time PCR) } \\
\text { - Just a small amount of test material that may be partially } \\
\text { degraded is needed (except for RFLP-PCR and tests } \\
\text { detecting viral RNA) }\end{array}$ & $\begin{array}{l}\text { - No possibility of comparing the } \\
\text { results (credibility) of the study in } \\
\text { the case of unlicensed assays with } \\
\text { primers of one's own design } \\
\text { - The possibility of contamination } \\
\text { of the sample by previous reactions } \\
\text { and therefore false-positive results }\end{array}$ \\
\hline $\begin{array}{l}\text { Signal } \\
\text { amplification } \\
\text { based methods }\end{array}$ & $\begin{array}{l}\text { - There are standardized commercial kits for the detection } \\
\text { of HPV DNA } \\
\text { - They allow quantitative assessment of HPV particles } \\
\text { in the sample } \\
\text { - High sensitivity and efficiency } \\
\text { - Highly reproducible methods } \\
\text { - Highly automated assays } \\
\text { - The genetic material may be partially degraded }\end{array}$ & $\begin{array}{l}\text { - They allow one only to classify } \\
\text { the virus genotype to groups of } \\
\text { medium/high and low risk HPV } \\
\text { (no possibility to identify individual } \\
\text { virus genotypes in multiple HPV } \\
\text { infections, no possibility to detect/ } \\
\text { identify new HPV genotypes) }\end{array}$ \\
\hline $\begin{array}{l}\text { Nucleic acid } \\
\text { hybridization } \\
\text { assays }\end{array}$ & $\begin{array}{l}\text { - Southern blotting - high specificity } \\
\text { - ISH, FISH, CISH - they can be performed on any kind } \\
\text { of material } \\
\text { - ISH allows one to specify the distribution of HPV in the } \\
\text { compartments of the sample (the relationship between } \\
\text { location of the virus and histopathological image) }\end{array}$ & $\begin{array}{l}\text { - Southern blotting requires a large } \\
\text { amount of highly purified, non-de- } \\
\text { graded DNA (impossible to per- } \\
\text { form on paraffin specimens) } \\
\text { - Low sensitivity } \\
\text { - Time-consuming, cumbersome } \\
\text { techniques }\end{array}$ \\
\hline
\end{tabular}

\section{Polymerase chain reaction}

Theoretically, 30 cycles of PCR reaction allow one to multiply a single copy of the desired double-stranded DNA fragment into a billion copies, and the DNA used for the test may be partially degraded. This enables the analysis of even small amounts of blood, in vitro cell cultures, saliva, urine, samples taken during thin-needle biopsy or histological sections fixed and embedded in paraffin. Sensitivity and specificity of the method vary depending on the set of primers used, the size of the tested DNA, conditions of the reaction, the polymerase used, and the amount and type of the replicated HPV [21]. Universal primers are most commonly used for the diagnosis of HPV, enabling one to detect all types of HPV, as the replication sequences are located in a highly conserved $\mathrm{L} 1$ region. These are GP 5/6 primer pairs and their extended version GP 5+/6+, as well as MY 09/MY
11 and the modified version PGMY 09/11 [28]. Oncogene primers are also used: $\mathrm{pU}-1 \mathrm{M}$ corresponding to the $\mathrm{E} 6$ gene sequence, $\mathrm{pU}-2 \mathrm{R}$ corresponding to the E7 gene sequence, and CPI and CPII for the E1 region $[29,30]$.

A kit detecting 13 high-risk types of HPV viruses with primer size of 170 base pairs (bp) complementary to the L1 region (Human Papillomavirus Amplicor test kit, Roche Diagnostics, California, USA) is commercially available [31]. Kits with shorter primers for the L1 region (65 bp for GP primers and $450 \mathrm{bp}$ for MY 09/11) are also used, as well as a kit with $65 \mathrm{bp}$ primers complementary to SPF10 [32]. Tests based on shorter primers are considered more sensitive and applicable also to partially degraded genetic material of the virus. Self-designed primers can also be used. It should be noted that studies based on non-commercial primer sets are not sufficiently standardized, 
and therefore cannot be compared with patented kits [33]. Polymerase chain reaction techniques may give false positive results due to the possibility of contamination of both sample and reagents with previously replicated amplicons. This problem can be eliminated by enzymatic destruction of the amplicons using uracil N-glycosylase (AmpErase) [31].

\section{Real-time polymerase chain reaction}

Quantitative tests enable precise determination of the amount of the virus in a certain amount of test material. The amount of the amplified, fluorescently labeled product is measured in real time by special detection systems in a thermocycler. Real-time PCR is the most sensitive method for detection of HPV DNA [33].

\section{Nucleic acid sequence based amplification}

Recently, HPV-RNA detecting methods are becoming more and more popular. They not only reflect the presence of HPV in the tested cells, but also provide information about the expression of the HPV genome. It is of great importance for the identification of clinically significant HPV infections. The commercially available test is based on real-time single-stranded RNA amplification, detecting E6/E7 region transcripts of HPV 16, 18, 31, 35 and 45 (HPV-Proofer PreTect, Norchip, West-Fjorden, Norway) [34].

\section{Transcription-mediated amplification}

The APTIMA HPV assay, employing the TMA method for detection of viral E6/E7 mRNA for 14 types of HPV (16/18/31/33/35/39/45/51/52/56/58/ $59 / 66 / 68$ ) is available. Target mRNA is isolated from the sample with a capture system, which uses magnetic microparticles. Capture oligomers contain sequences complementary to specific target regions of the HPV mRNA, and other parts of the deoxyadenosine chain. Complementary regions hybridize. Then oligomer/ target region mRNA complexes are captured from the solution by lowering the temperature of the mixture to room temperature to allow hybridization between the deoxyadenosine regions on the capture oligomer and poly-deoxythymidine of the molecule, which is covalently attached to a particle with magnetic properties. Magnetic particles, including 13 bound and captured target HPV mRNA molecules, are isolated from the reaction mixture by means of magnets. Human papillomavirus mRNA is then amplified with the TMA technique, which uses transcription of nucleic acid similar to NASBA. It utilizes two enzymes: reverse transcriptase and RNA polymerase. Reverse transcriptase is used to create a DNA copy of the mRNA target sequence, comprising a promoter sequence for RNA polymerase. T7 RNA polymerase produces multiple copies of the RNA amplicon from the DNA template [35].

\section{Reverse transcription polymerase chain reaction}

Messenger RNA (mRNA) is used as a template for synthesis of cDNA (complementary DNA, containing only sequences from the mature mRNA, so the exons only), using reverse transcriptase (RT). The DNA is then amplified with a normal PCR reaction. This method is mainly used for detection of E6 and E7 gene transcription products. The major disadvantage of this method, and all methods based on the detection of viral RNA, is the lability of ribonucleic acid molecules. The sensitivity of these methods depends on the time, preparation method and storage of the samples [31].

\section{Amplification of papillomavirus oncogene transcripts (APOT) method}

It allows one to distinguish HPV oncogenic transcription products integrated into the patient genome from episomal RNA [36].

\section{Polymerase chain reaction-restriction fragment length polymorphism}

This method involves digestion of the amplified PCR products using restriction endonucleases and their analysis after electrophoretic separation on a polyacrylamide gel. The disadvantage of this method is that the analysis can only be performed on non-degraded, highly-purified DNA [31, 37].

\section{Nested polymerase chain reaction}

A technique particularly useful when a sample contains a small amount of DNA templates. It is carried out in two stages. First, synthesis of a few long DNA chains is performed, containing the target fragment of the viral genome (so the study material is amplified). Then primers surrounding the tested fragment are added and other PCR steps follow [38].

An overview of commercially available kits for detection of the HPV genome, including readout methods, is presented in Table III.

\section{Signal amplification based methods}

These methods increase the sensitivity of the assay due to the reaction occurring between the ligands that label a probe (fluorescent dyes, biotin or digoxigenin), and specific antibodies conjugated with particular enzymes (such as alkaline phosphatase or peroxidase). Following the addition of a substrate a colorimetric or chemiluminescent reaction occurs.

\section{Branched DNA (bDNA) method}

The assay is based on hybridization of synthetic oligonucleotides complementary to the target sequence of the HPV genome. The formed complex 
Table III. Review of available commercial kits for the detection of HPV genome and the readout methods

\begin{tabular}{|c|c|c|c|}
\hline $\begin{array}{l}\text { TEST NAME/ } \\
\text { MANUFAC- } \\
\text { TURER }\end{array}$ & TYPES OF HPV VIRUS DETECTED & $\begin{array}{c}\text { GENETIC } \\
\text { MATERIAL }\end{array}$ & DETECTION METHOD \\
\hline \multicolumn{4}{|c|}{ Detection and assignment of HPV viruses to groups, without determining HPV type } \\
\hline $\begin{array}{l}\text { AMPLICOR } \\
\text { HPV Test/ } \\
\text { Roche } \\
\text { Molecular } \\
\text { Systems }\end{array}$ & $\begin{array}{l}\text { high-risk HPV: } \\
16,18,31,33,35,39,45,51,52,56,58,59 \\
68\end{array}$ & $\begin{array}{l}\text { DNA } \\
\text { L1: } 170 \text { bp }\end{array}$ & $\begin{array}{l}\text { PCR with biotinylated primers, read- } \\
\text { out - hybridization with antibodies } \\
\text { fixed on a plate and a color reaction } \\
\text { after addition of horseradish peroxi- } \\
\text { dase }\end{array}$ \\
\hline $\begin{array}{l}\text { AID HPV } \\
\text { screening } \\
\text { kit/GenID } \\
\text { GmbH }\end{array}$ & $\begin{array}{l}\text { 1) high-risk HPV: } \\
\text { 16, 18, 31, 33, 35, 39, 45, 51, 52, 56, 58, 59, } \\
66,68,73,82 \\
\text { 2) low-risk HPV: } \\
6,11,40,42,43,44\end{array}$ & $\begin{array}{l}\text { DNA } \\
\text { E1 }\end{array}$ & $\begin{array}{l}\text { PCR, reverse hybridization strip assay, } \\
\text { colorimetric readout }\end{array}$ \\
\hline $\begin{array}{l}\operatorname{cobas}{ }^{\circledR} \\
4800 \mathrm{HPV} \\
\text { Test/Roche } \\
\text { Molecular } \\
\text { Systems }\end{array}$ & $\begin{array}{l}16,18,31,33,35,39,45,51,52,56,58,59, \\
66,68 \\
\text { Differentiation between HPV } 16 \text { and } 18\end{array}$ & $\begin{array}{l}\text { DNA } \\
\text { L1: } 200 \mathrm{bp}\end{array}$ & $\begin{array}{l}\text { PCR, the detection of amplicons is } \\
\text { performed during heat treatment by } \\
\text { using oligonucleotide probes labeled } \\
\text { with four different fluorescent dyes }\end{array}$ \\
\hline $\begin{array}{l}\text { RealTime } \\
\text { High Risk } \\
\text { HPV test / } \\
\text { Abbott }\end{array}$ & $\begin{array}{l}16,18,31,33,35,39,45,51,52, \\
56,58,59,66,68 \\
\text { Differentiation between samples with or with- } \\
\text { out HPV 16/18 }\end{array}$ & $\begin{array}{l}\text { DNA } \\
\text { L1 }\end{array}$ & $\begin{array}{l}\text { Real-time PCR, multicolor detection } \\
\text { system in the last } 38 \text { cycles }\end{array}$ \\
\hline $\begin{array}{l}\text { APTIMA } \\
\text { HPV Test/ } \\
\text { Gen-Probe }\end{array}$ & $\begin{array}{l}16,18,31,33,35,39,45,51,52,56,58,59 \\
66,68\end{array}$ & $\begin{array}{l}\text { mRNA } \\
\text { E6 E7 }\end{array}$ & $\begin{array}{l}\text { TMA/ } \\
\text { chemiluminescent labeling }\end{array}$ \\
\hline $\begin{array}{l}\text { PreTect } \\
\text { HPVProofer/ } \\
\text { Norchip }\end{array}$ & $16,18,31,33,45$ & $\begin{array}{l}\text { mRNA } \\
\text { E6 E7 }\end{array}$ & $\begin{array}{l}\text { NASBA, real-time detection of prod- } \\
\text { ucts }\end{array}$ \\
\hline $\begin{array}{l}\text { NucliSENS } \\
\text { EasyQ HPV/ } \\
\text { bioMérieux }\end{array}$ & $16,18,31,33,45$ & $\begin{array}{l}\text { mRNA } \\
\text { E6 E7 }\end{array}$ & $\begin{array}{l}\text { NASBA, real-time detection of prod- } \\
\text { ucts }\end{array}$ \\
\hline
\end{tabular}

\begin{tabular}{|c|c|c|c|}
\hline \multicolumn{4}{|c|}{ Detection of specific types of HPV viruses } \\
\hline $\begin{array}{l}\text { digene HPV } \\
\text { Genotyping } \\
\text { RH Test/ } \\
\text { Qiagen }\end{array}$ & $\begin{array}{l}16,18,26,31,33,35.39,45,51,52,53,56 \\
58,59,66,68,73,82\end{array}$ & DNA & $\begin{array}{l}\text { PCR (primers GP5 }+/ 6+\text { ), reverse } \\
\text { hybridization }\end{array}$ \\
\hline $\begin{array}{l}\text { digene HPV } \\
\text { Genotyping } \\
\text { LQ! Test/ } \\
\text { Qiagen }\end{array}$ & $\begin{array}{l}16,18,26,31,33,35.39,45,51,52,53,56 \\
58,59,66,68,73,82\end{array}$ & DNA & $\begin{array}{l}\text { PCR (primers GP5 }+/ 6+\text { ), LiquiChip } \\
\text { detection system using xMAP technol- } \\
\text { ogy }\end{array}$ \\
\hline $\begin{array}{l}\text { INNO LiPA } \\
\text { HPV } \\
\text { Genotyping } \\
\text { Extra/ } \\
\text { Innogenetics }\end{array}$ & $\begin{array}{l}6,11,16,18,26,31,33,35,39,40,43,44 \\
45,51,52,53,54,56,58,59,66,68 / 73,69 \\
70 ; 71,74,82\end{array}$ & $\begin{array}{l}\text { DNA } \\
\text { L1 } \\
\text { (SPF10): } \\
65 \mathrm{bp}\end{array}$ & $\begin{array}{l}\text { PCR/solid-phase reverse hybridization } \\
\text { (membrane strips) and enzymatic } \\
\text { color reaction }\end{array}$ \\
\hline
\end{tabular}


Table III. cont.

\begin{tabular}{|c|c|c|c|}
\hline $\begin{array}{l}\text { TeST NAME/ } \\
\text { ManUfaC- } \\
\text { TURER }\end{array}$ & TyPES OF HPV VIRUS DETECTED & $\begin{array}{l}\text { GENETIC } \\
\text { MATERIAL }\end{array}$ & DETECTION METHOD \\
\hline $\begin{array}{l}\text { SPF10- } \\
\text { LiPA25/ } \\
\text { Labo Bio- } \\
\text { medical } \\
\text { Products }\end{array}$ & $\begin{array}{l}6,11,16,18,31,33,34,35,39,40,42,43, \\
44,45,51,52,53,54,56,58,59,66,68,70 \\
74\end{array}$ & $\begin{array}{l}\text { DNA } \\
\text { L1 (SPF10) }\end{array}$ & $\begin{array}{l}\mathrm{PCR} / \text { solid-phase reverse hybridization } \\
\text { (membrane strips) and enzymatic } \\
\text { color reaction }\end{array}$ \\
\hline $\begin{array}{l}\text { HPV-DNA } \\
\text { Chip/ } \\
\text { Biomedlab }\end{array}$ & $\begin{array}{l}6,11,16,18,31,33,34,35,39,40,42,43 \\
44,45,51,52,56,58,59,66,68,69\end{array}$ & $\begin{array}{l}\text { DNA } \\
\text { L1 }\end{array}$ & $\begin{array}{l}\text { PCR, microarray with specific oligo } \\
\text { probes }\end{array}$ \\
\hline $\begin{array}{l}\text { LINEAR } \\
\text { ARRAY } \\
\text { HPV } \\
\text { Genotyping } \\
\text { Kit/ } \\
\text { Roche } \\
\text { Molecular } \\
\text { Systems }\end{array}$ & $\begin{array}{l}6,11,16,18,26,31,33,35,39,40,42,45 \\
51,52,53,54,55,56,58,59,61,62,64 \\
66,67,68,69,70,71,72,73 \text { (MM9), 81, } 82 \\
\text { (MM4), 83 (MM7), } 84 \text { (MM8), IS39, CP6108 }\end{array}$ & $\begin{array}{l}\text { DNA } \\
\text { L1: 450bp }\end{array}$ & $\begin{array}{l}\text { PCR (PYGMY consensus primers), } \\
\text { solid-phase reverse hybridization (line } \\
\text { blot) and enzymatic color reaction }\end{array}$ \\
\hline $\begin{array}{l}\text { Papillocheck/ } \\
\text { Greiner } \\
\text { Bio-One }\end{array}$ & $\begin{array}{l}6,11,16,18,31,33,35,39,40,42,44,45 \\
51,52,53,55,56,58,59,66,68,70,73,82 \\
\text { (44 and } 55 \text { together) }\end{array}$ & $\begin{array}{l}\text { DNA } \\
\text { E1: } 350 \mathrm{bp}\end{array}$ & $\begin{array}{l}\text { PCR (consensus primers), oligo probes } \\
\text { immobilized in a DNA microarray }\end{array}$ \\
\hline $\begin{array}{l}\text { PCR HPV } \\
\text { Typing Set/ } \\
\text { Takara Bio } \\
\text { Inc. }\end{array}$ & $\begin{array}{l}\text { 1) high-risk HPV: } \\
\text { 16, 18, 33, 52b, } 58 \\
\text { 2) low-risk HPV: } \\
\text { 6, } 11\end{array}$ & $\begin{array}{l}\text { DNA } \\
\text { E6 E7: } \\
\text { 300bp }\end{array}$ & $\begin{array}{l}\text { PCR (consensus primer pairs: } \mathrm{pU}-\mathrm{M} / \\
\mathrm{pU}-2 \mathrm{R} \text { and } \mathrm{pU}-3 \mathrm{~B} / \mathrm{pU}-2 \mathrm{R} \text { ), electro- } \\
\text { phoretic separation of products on an } \\
\text { agarose gel }\end{array}$ \\
\hline $\begin{array}{l}\text { PCR HPV } \\
\text { Detection } \\
\text { Set/ } \\
\text { Takara Bio } \\
\text { Inc. }\end{array}$ & $16,18,33$ & $\begin{array}{l}\text { DNA } \\
\text { E6:140bp }\end{array}$ & $\begin{array}{l}\text { PCR, electrophoretic separation of } \\
\text { products on an agarose gel or using } \\
\text { dot blot }\end{array}$ \\
\hline $\begin{array}{l}\text { HPV HR } \\
\text { Genotyping } \\
\text { Assay/ } \\
\text { GenoID }\end{array}$ & $\begin{array}{l}16,18,31,33,35,39,45,51,52,56,58,59 \\
66,68\end{array}$ & $\begin{array}{l}\text { DNA } \\
\text { L1 }\end{array}$ & $\begin{array}{l}\text { PCR, solid-phase hybridization and } \\
\text { enzymatic color reaction }\end{array}$ \\
\hline $\begin{array}{l}\text { Full } \\
\text { Spectrum } \\
\text { HPV Assay/ } \\
\text { GenoID }\end{array}$ & $\begin{array}{l}\text { 1) high-risk HPV: } \\
\text { 16, 18, 31, 33, 35, 39, 45, 51, 52, 56, 58, 59, } \\
\text { 66, } 68 \\
\text { 2) low-risk HPV: } \\
\text { 6, 11, 42, 43, 44/55 } \\
\text { 3) other: } \\
\text { 2, 3, 7, 10, 13, 26, 27, 28, 29, 30, 34, 40, 53, } \\
54,57,61,67,70,72,73,74,81,82,83,84 \text {, } \\
85,89,90,91\end{array}$ & $\begin{array}{l}\text { DNA } \\
\text { L1 }\end{array}$ & $\begin{array}{l}\text { PCR, solid-phase hybridization and } \\
\text { enzymatic color reaction }\end{array}$ \\
\hline
\end{tabular}


Table III. cont.

\begin{tabular}{|c|c|c|c|}
\hline AID HPV & 1) $6,11,16,18,45$ & DNA & \multirow{5}{*}{$\begin{array}{l}\text { PCR, reverse hybridization strip assay, } \\
\text { colorimetric readout }\end{array}$} \\
\hline typing kit/ & 2) quantitative detection of high-risk HPV: & E1 & \\
\hline GenID & $(31,33,35,39,51,52,53,56,58,59)$ & & \\
\hline \multirow[t]{2}{*}{$\mathrm{GmbH}$} & 3) nonspecific detection of HPV: & & \\
\hline & $66,68,73,82,40,42,43,44$ & & \\
\hline CLART & \multirow{3}{*}{$\begin{array}{l}6,11,16,18,26,31,33,35,39,40,42,43 \\
44,45,51,52,53,54,56,58,59,61,62,66 \\
68,70,71,72,73,81,82,83,84,85,89\end{array}$} & DNA & \multirow{3}{*}{$\begin{array}{l}\text { PCR, biotinylated amplicons hybrid- } \\
\text { ize with specific probes in solid phase } \\
\text { (microarray), readout with enzymatic } \\
\text { color reaction }\end{array}$} \\
\hline HPV2/ & & $\mathrm{L} 1: 450 \mathrm{bp}$ & \\
\hline Genomica & & & \\
\hline ProDect & \multirow{5}{*}{$\begin{array}{l}6,11,16,18,31,33,35,39,42,43,44,45 \\
51,52,56,58,59,68,73\end{array}$} & DNA & \multirow[t]{5}{*}{ PCR, reverse hybridization strip assay } \\
\hline Chip HPV & & $\mathrm{E} 6 / \mathrm{E} 7$ & \\
\hline Typing/Bcs & & $\mathrm{L} 1$ & \\
\hline \multirow{2}{*}{\multicolumn{2}{|c|}{$\begin{array}{l}\text { Biotech } \\
\text { S.p.A }\end{array}$}} & & \\
\hline & & & \\
\hline \multirow{2}{*}{$\begin{array}{l}\text { Chipron } \\
\text { HPV 3.5/ } \\
\text { Chipron }\end{array}$} & $6,11,16,18,31,33,35,39,42,44,45,51$ & No data & $\mathrm{PCR} /$ reverse hybridization on a mi- \\
\hline & $\begin{array}{l}52,53,54,56,58,59,61,62,66,67,68,70 \\
72,73,81,82,83,84,90,91\end{array}$ & & croarray and enzymatic color reaction \\
\hline PapType/ & \multirow{4}{*}{$\begin{array}{l}6,11,16,18,31,33,35,39,45,51,52,56 \\
58,59,66,68\end{array}$} & \multirow{4}{*}{ DNA } & \multirow{4}{*}{$\begin{array}{l}\text { PCR, detection of amplicons using } \\
\text { fluorescently labeled oligonucleotide } \\
\text { probes, fluorescence measurement } \\
\text { using flow cytometry }\end{array}$} \\
\hline Genera & & & \\
\hline & & & \\
\hline Biosystems & & & \\
\hline \multirow{3}{*}{$\begin{array}{l}\text { F-HPV } \\
\text { typing/ } \\
\text { molGENTIX }\end{array}$} & \multirow{3}{*}{$\begin{array}{l}6,11,16,18,31,33,35,39,45,51,52,56 \\
58,59,68\end{array}$} & DNA & \multirow{3}{*}{$\begin{array}{l}\text { multiplex PCR with a set of } 16 \\
\text { fluorescently labeled primers (product } \\
\text { identification by color and size by } \\
\text { electrophoresis) }\end{array}$} \\
\hline & & E6 E7 & \\
\hline & & & \\
\hline
\end{tabular}

hybridizes with a synthetic, branched DNA molecules (bDNA), labeled with an enzyme. The resultant ternary complex is incubated with a suitable substrate with chemiluminescent properties, which leads to a chemiluminescent reaction, allowing one to measure the intensity of the reaction. This technique allows the detection of minimal quantities of test material. There is a commercially available assay produced by Bayer company [39].

\section{Hybrid Capture hybridization assay}

The test uses RNA probes, which hybridize with the target HPV DNA. Then, RNA-DNA hybrids are detected by enzyme-labeled antibodies. The signal amplification is achieved through a set of antibodies conjugated with alkaline phosphatase. The outcome of the chemiluminescent reaction provides semi-quantitative results. Detection of HPV using Hybrid Capture 2 genetic probes (Digene Diagnostics, Gaithersburg, MD, USA) is a test recognized by the American Food and Drug Agency (FDA) in molecular diagnostics of HPV infections of the urogenital area. This test enables the classification of the detect- ed viral genotypes into two groups: low risk viruses $6,11,42,43,44$, and medium/high risk viruses 16 , $18,31,33,35,39,45,51,52,56,58,59,68$. This assay has a high sensitivity. It can detect 5000 copies of viral DNA in one sample or 1 pg of HPV DNA in one sample. The disadvantage of this method is that it does not allow one to define different HPV types in the sample [40]. Presently, a third generation Hybrid Capture test (HC3) is available. The major difference between the generations of the assays is the use of biotinylated oligonucleotides in HC3 instead of antibodies against DNA-RNA hybrids. Due to biotin-labeled oligonucleotides specific for the selected HPV DNA sequences, the DNA-RNA hybrids are captured and combined in complexes with streptavidin coating plate wells. Such modification of the test reduces the risk of non-specific binding of DNARNA hybrids resulting from insufficient alkaline denaturation of samples [41].

\section{The Cervista test}

This method is based on detecting the presence of HPV in liquid phase, using the so-called invad- 
er assay, developed by Hologic (Cervista HR HPV/ Hologic). It enables the detection of high-risk HPV types and it consists of two parallel isothermal reactions [42]. The basic reaction detects the presence of high-risk HPV by hybridization of two oligonucleotides: invader oligonucleotide and an oligonucleotide probe, which are DNA fragments that do not contain biotin or any conjugated enzyme. This reaction is similar to that used in the HC2 assay, in which the RNA probe hybridizes with denatured HPV DNA. In the invader assay the two oligonucleotides hybridize together with the target HPV DNA sequence to form a triple structure due to the lack of complementarity between the terminal nucleotide sequence at the 3' end of the invader oligonucleotide and the probe fragment attached to the target viral DNA. A triple structure is thus created, which consists of the DNA-DNA duplex formed in the hybridization between the probe and the oligo DNA of the target HPV and overlapping of the DNA-DNA duplex of non-complementary invader oligonucleotide and the probe. This unusual structure, not normally present in the patient material, is therefore recognized by an enzyme with 5' nuclease activity, which cuts its fragment - a reporter DNA called " 5 ' flap". The freed 5' fragment enables the detection of the signal in a subsequent reaction due to fluorescence resonance energy transfer (FRET). There is also another test based on the same methodology, manufactured by the same company, that detects HPV 16 and 18 (Cervista HPV 16/18/ Hologic).

\section{Nucleic acid hybridization assays}

\section{Southern blotting}

It is a research method used for identifying new types of viruses [43]. It allows one to specify whether the tested sample of genetic material is episomal or integrated DNA. This technique detects up to 0.1 virus copies per cell. Southern blotting hybridization on solid phase (nylon membrane) can be carried out only on intact, full-size particles of the viral DNA and is therefore not suitable for the analysis of samples with partially degraded genetic material (sections, specimens stored in formalin) [33]. In order to obtain reliable results using this method it is necessary to analyze a large number of highly purified nucleic acids [21]. Commercial kits for the detection of HPV are not available, and the process of analysis is complicated (it requires a well-equipped laboratory with staff qualified in advanced laboratory techniques). Cloned genome HPV probes, often labeled with radioisotopes, are used for hybridization [43]. Some authors have suggested that the specificity of such hybridization may be higher than in methods using polymerase chain reaction, with sensitivity lower than in PCR [44].

\section{Northern blotting}

Advantages and disadvantages of this method are similar to those of Southern blotting. It detects specific sequences of viral RNA. It is used to detect mRNA of HPV genes undergoing transcription in the cell [45].

\section{Dot blotting}

This hybridization method is similar to the two aforementioned ones. The main difference is that in the dot blot method, the nucleic acids are not separated by using electrophoresis, but directly applied to the membrane, and immobilized on nylon or nitrocellulose membranes in the form of staining [43]. Total DNA or RNA, isolated from the test material, can be subjected to hybridization with molecular probes. The signal is detected if the probe recognizes a complementary nucleotide sequence. This method is also possible to perform in a reversed situation, where the probe is immobilized in solid phase, and the tested material is added in a solution. A major limitation of dot blotting in the detection of HPV is its low sensitivity [43]. Until recently, it was possible to apply kits manufactured by Digene - Virapap and Viratype. Currently, these products are unavailable [40].

\section{In situ hybridization}

In situ hybridization (ISH) can be performed directly on bioptates and solid tissues (paraffin specimens), so it allows one to locate the target viral sequences in cell structures, and therefore to relate their localization to histopathological images. Using this method, messenger RNA (mRNA) of the virus can be detected, as a marker of expression of particular genes if the amount of HPV protein is low [46]. Nucleic acid probes for ISH are generally labeled with biotin, and they are usually detected by a specific labeled probe due to a reaction of streptavidin and a chromogen. The main limitation of this method is its low sensitivity - according to different authors ISH detects a minimum of 10 to 25 copies of viral DNA per cell [20]. Moreover, there is a risk of mistyping HPV due to the possibility of cross hybridization between the probes [5]. To increase the sensitivity, a method known as in situ PCR was introduced, joining ISH with PCR. In situ PCR is a polymerase chain reaction performed inside the cell. This technique is performed on fixed tissue or cells. The choice of fixative is essential for in situ PCR and may affect the sensitivity of this method. A good fixative should permit adequate amplification in the nuclei and prevent migration of the PCR product out of the cell. This method allows the identification of cellular markers and permits the localization of specific sequences within cells and tissues. Due to copy number limitations, hybridization of RNA is more sensitive than DNA detection [47]. 
Table IV. Comparison of CISH and FISH in the detection of HPV

\begin{tabular}{lll}
\hline Archiving of the result & Possible & \multicolumn{1}{c}{ FISH } \\
\hline Readout method & Optical microscope & $\begin{array}{l}\text { The quality deteriorates due to the } \\
\text { passage of time }\end{array}$ \\
\hline Magnification & $40 \times$ & Fluorescence microscope \\
\hline Length of protocol & $3-5 \mathrm{~h}$ & $60-100 \times$ \\
& $\begin{array}{l}\text { min. } 1 \mathrm{~h} \\
\text { (depending on the internal reaction } \\
\text { conditions) }\end{array}$ & $\begin{array}{l}3-5 \mathrm{~h} \\
\text { (depending on the internal reaction } \\
\text { conditions) }\end{array}$ \\
\hline Degree of skill required & Average & High \\
\hline Internal control of the test accuracy & Yes & Yes \\
\hline Interpretation of the result & Objective/quantitative & Objective/quantitative \\
\hline Total cost & Average & High \\
\hline CISH - cbromogenic in situ hybridization, FISH - fluorescence in situ hybridization &
\end{tabular}

In this method, amplification of target DNA by PCR is initially carried out with primers for the $\mathrm{L} 1$ region nucleotide sequence. Then, oligonucleotide probes are added to the resulting, biotin-labeled amplicons and hybridization occurs. In order to obtain a color reaction, a conjugate of avidin with horseradish peroxidase is added and the absorbance of the sample is measured. The advantage of this method is its ability to detect inhibitors of amplification and improperly collected samples - a kit for $\beta$-globin gene amplification is attached [48]. There are various types of ISH, which differ primarily in the methods of probe labeling, and in the read-out systems.

\section{Fluorescence in situ hybridization}

In this technique, hybridization probes labeled with fluorochromes are used, and the images are observed under a fluorescence microscope [49]. Another type of ISH used for detection of HPV is chromogenic ISH [49].

\section{Chromogenic in situ hybridization}

This technique uses labeled RNA or DNA probes to identify specific sequences of HPV genome in the investigated samples. Chromogenic in situ hybridization (CISH) uses conventional reactions of peroxidase or alkaline phosphatase, allowing the test result to be read under a standard optical microscope. The analysis can be performed on solid samples (sections, biopsies) stored in formalin, embedded in paraffin, fresh and frozen preparations. This is an alternative method to FISH (Table IV). Some authors suggest that FISH is slightly more sensitive and specific than $\mathrm{CISH}$ [50].

Two kits using ISH methods are commercially available: one using the indirect binding of strepta- vidin and biotin (Ventana Inform HPV Tucson, AZ, USA), and a second alternative set using Tyramide Signal Amplification (Dako GenPoint, Glostrup, Denmark) [51, 52].

\section{Summary}

In summary, there are many different assays detecting the presence of HPV. Each of them has certain technical, analytical and clinical characteristics. That is why the choice between them should be made not only for practical reasons, but also according to the intentions of use. Although many studies have been performed, sofar there is no algorithm that is most appropriate for the detection of clinically relevant HPV infections and most reliable in assessing the prognosis of patients with HPV-related cancers. However, from a clinical viewpoint, in HNSCC tumors of primary location in the oropharynx, molecular diagnostics for the presence of HPV should be performed in addition to the classical histopathological examination. According to the National Comprehensive Cancer Network 2013 guidelines, immunohistochemical determination of p16 oncogene or detection of HPV DNA in the nucleus of the tumor tissue using ISH is recommended for prognosis determination in head and neck cancers [53]. The College of American Pathologists recommends performing assays monitoring the presence of HPV DNA in oropharynx squamous cell carcinoma depending on p16 $6^{\text {INK4a }}$ expression in immunohistochemistry together with cancer morphology assessment. According to this association, confirmation of the presence of viral DNA is required for:

- non-keratinizing or mostly non-keratinizing carcinomas, when immunohistochemical staining is negative or only focally positive, 
- keratinized carcinomas with a strong and (cytoplasmic and nuclear above 70\%).

There is no need to confirm the presence of HPV DNA in:

- keratinizing carcinomas with a negative or only focally positive reaction in immunohistochemistry, or:

- non-keratinizing or mostly non-keratinizing carcinomas with a strong and diffuse immunohistochemical reaction.

Morphological assessment of HPV-related cancers is still essential in histopathological examination. In HPV-positive tumors, apart from confirmation of koilocytosis, it is obligatory to perform additional assays for detection of human papillomavirus proteins (being indirect proof of viral infection) or genome.

Authors declare no conflict of interest.

\section{References}

1. Bernard HU, Burk RD, Chen Z, et al. Classification of papillomaviruses (PVs) based on $189 \mathrm{PV}$ types and proposal of taxonomic amendments. Virology 2010; 401: 70-79.

2. Campisi G, Panzarella V, Giuliani M, et al. Human papillomavirus: its identity and controversial role in oral oncogenesis, premalignant and malignant lesions (review). Int J Oncol 2007; 30: 813-823.

3. Więcławska M, Kukwa A, Malejczyk M, et al. Zakażenie wirusem brodawczaka ludzkiego (HPV) w obrębie jamy ustnej i gardła. Czas Stomat 2005; 58: 689-702.

4. Esquenazi D, Bussoloti Filho I, Carvalho Mda G, et al. The frequency of human papillomavirus findings in normal oral mucosa of healthy people by PCR. Braz J Otorhinolaryngol 2010; 76: 78-84

5. Kumaraswamy KL, Vidhya M. Human papilloma virus and oral infections: An update. J Cancer Res Ther 2011; 7: 120127.

6. Zhang ZY, Sdek P, Cao J, et al. Human papillomavirus type 16 and 18 DNA in oral squamous cell carcinoma and normal mucosa. Int J Oral Maxillofac Surg 2004; 33: 71-74.

7. Chaudhary AK, Singh M, Sundaram S, et al. Role of human papillomavirus and its detection in potentially malignant and malignant head and neck lesions: update review. Head Neck Oncol 2009; 1: 22.

8. Szyfter K, Wierzbicka M. Rola wirusa brodawczaka (HPV) w nowotworach głowy i szyi. Postępy w Chirurgii Głowy i Szyi 2008; 2: 41-50.

9. zur Hausen H. Papillomaviruses causing cancer: Evasion from host-cell control in early events in carcinogenesis. J Natl Cancer Inst 2000; 92: 690-698.

10. Syrjänen S. Human papillomavirus (HPV) in head and neck cancer. J Clin Virol 2005; 32: 59-66.

11. Smeets SJ, van der Plas M, Schaaij-Visser TB, et al. Immortalization of oral keratinocytes by functional inactivation of the p53 and pRb pathways. J Cancer 2011; 128: 1596-1605.

12. Klussmann JP, Mooren JJ, Lehnen M, et al. Genetic signatures of HPV-related and unrelated oropharyngeal carcinoma and their prognostic implications. Clin Cancer Res 2009; 15: 1779-1786

13. Stephen JK, Divine G, Chen KM, et al. Significance of p16 in site-specific HPV positive and HPV negative head and neck squamous cell carcinoma. Cancer Clin Oncol 2013; 2: 51-61.
14. Lohavanichbutr P, Houck J, Fan W, et al. Genomewide gene expression profiles of HPV-positive and HPV-negative oropharyngeal cancer: potential implications for treatment choices. Arch Otolaryngol Head Neck Surg 2009; 135: 180-188.

15. Sinha P, Logan HL, Mendenhall WM. Human papillomavirus, smoking, and head and neck cancer. Am J Otolaryngol 2012; 33: $130-136$

16. Duray A, Descamps G, Decaestecker C, et al. Human papillomavirus DNA strongly correlates with a poorer prognosis in oral cavity carcinoma. Laryngoscope 2012; 122: 1558-1565.

17. Gillison ML, D'Souza G, Westra W, et al. Distinct risk factor profiles for human papillomavirus type 16-positive and human papillomavirus type 16-negative head and neck cancers. J Natl Cancer Inst 2008; 100: 407-420.

18. Lindeberg H, Syrjänen S, Kärjä J, et al. Human papillomavirus type 11 DNA in squamous cell carcinomas and pre-existing multiple laryngeal papillomas. Acta Otolaryngol 1989; 107: 141-149.

19. von Buchwald C, Bradley PJ. Risks of malignancy in inverted papilloma of the nose and paranasal sinuses. Curr Opin Otolaryngol Head Neck Surg 2007; 15: 95-98.

20. Coutlée F, Rouleau D, Ferenczy A, et al. The laboratory diagnosis of genital human papillomavirus infections. Can J Infect Dis Med Microbiol 2005; 16: 83-91.

21. Villa LL, Denny L. Methods for detection of HPV infections and its clinical utility. Int J Gynaecol Obstet 2006; 94: 71-80.

22. Strati K, Pitot HC, Lambert PF. Identification of biomarkers that distinguish human papillomavirus (HPV) - positive vs. HPV - negative head and neck cancers in a mouse model. Proc Natl Acad Sci USA 2006; 103: 14152-14157.

23. Chang F, Syrjänen S, Kellokoski J, et al. Human papillomavirus infections and their associations with oral disease. J Oral Pathol Med 1991; 20: 305-310.

24. Sehr P, Müller M, Höpfl R, et al. HPV antibody detection by ELISA with capsid protein L1 fused to glutathione S-transferase. J Virol Methods 2002; 106: 61-70.

25. Hernandez BY, Ton T, Shvetsov YB, et al. Human papillomavirus (HPV) L1 and L1-L2 virus-like particle-based multiplex assays for measurement of HPV virion antibodies. Clin Vaccine Immunol 2012; 19: 1348-1352.

26. Abreu AL, Souza RP, Gimenes F, et al. A review of methods for detect human Papillomavirus infection. Virol J 2012; 9: 262.

27. Liss J, Łukaszuk K, Wójcikowski C. Zastosowanie łańcuchowej reakcji polimerazy - PCR w diagnozowaniu infekcji wirusem brodawczaka ludzkiego HPV. Diagn Lab 2002; 38: 53-60.

28. Gravitt PE, Jamshidi R. Diagnosis and management of oncogenic cervical human papillomavirus infection. Infect Dis Clin North Am 2005; 19: 439-458.

29. Godlewska-Zoładkowska K, Olszewska E, Chodynicki S, et al. Verrucous carcinoma-histological and molecular analysis. Otolaryngol Pol 2003; 57: 793-797.

30. Lindeberg H, Krogdahl A. Laryngeal cancer and human papillomavirus: HPV is absent in the majority of laryngeal carcinomas. Cancer Lett 1999; 146: 9-13.

31. Iftner T, Villa LL. Chapter 12: Human papillomavirus technologies. J Natl Cancer Inst Monogr 2003; 31: 80-88.

32. Kleter B, van Doorn LJ, ter Schegget J, et al. Novel short-fragment PCR assay for highly sensitive broad-spectrum detection of anogenital human papillomaviruses. Am J Pathol 1998; 153: 1731-1739.

33. Hubbard RA. Human papillomavirus testing methods. Arch Pathol Lab Med 2003; 127: 940-945.

34. Molden T, Kraus I, Karlsen F, et al. Comparison of $\mathrm{Hu}-$ man Papillomavirus messenger RNA and DNA detection: a cross-sectional study of 4,136 women $>30$ years of age with a 2 year follow-up of high-grade squamous intraepithelial lesion. Cancer Epidemiol Biomarkers Prev 2005; 14: 367-373. 
35. Hill CS. Molecular diagnostic testing for infectious diseases using TMA technology. Expert Rev Mol Diagn 2001; 1: 445455.

36. Klaes R, Woerner SM, Ridder R, et al. Detection of high-risk cervical intraepithelial neoplasia and cervical cancer by amplification of transcripts derived from integrated papillomavirus oncogenes. Cancer Res 1999; 59: 6312-6316.

37. Nobre RJ, Cruz E, Real O, et al. Characterization of common and rare human papillomaviruses in Portuguese women by the polymerase chain reaction, restriction fragment length polymorphism and sequencing. J Med Virol 2010; 82: 1024-1032.

38. Winder DM, Ball SL, Vaughan K, et al. Sensitive HPV detection in oropharyngeal cancers. BMC Cancer 2009; 9: 440.

39. Player AN, Shen LP, Kenny D, et al. Single-copy gene detection using branched DNA (bDNA) in situ hybridization. J Histochem Cytochem 2001; 49: 603-612.

40. Malloy C, Sherris J, Herdman C. HPV DNA testing: Technical and programmatic issues for cervical cancer prevention in low-resource settings. Path 2000. Dostępny na stronie: http:// www.path.org/publications/files/HPV-DNA-Testing-Issues. pdf. Date of access: 21 August 2013.

41. Castle PE, Lorincz AT, Scott DR, et al. Comparison between prototype Hybrid Capture 3 and Hybrid Capture 2 Human papillomavirus DNA assays for detection of high-grade cervical intraepithelial neoplasia and cancer. J Clin Microbiol 2003; 41: 4022-4030

42. Day SP, Hudson A, Mast A, et al. Analytical performance of the Investigational Use Only Cervista HPV HR test as determined by a multi-center study. J Clin Virol 2009; 45: S63-72.

43. Lorincz AT. Molecular methods for the detection of human papillomavirus infection. Obstet Gynecol Clin North Am 1996; 23: 707-730.

44. Frazer IH, Leonard JH, Schonrock J, et al. HPV DNA in oropharyngeal squamous cell cancer: comparison of results of four DNA detection methods. Pathol 1993; 25: 138-143.

45. Snijders PJ, Heideman DA, Meijer CJ, et al. Methods for HPV detection in exfoliated cell and tissue specimens. APMIS 2010; 118: $520-528$

46. Stoler MH, Wolinsky SM, Whitbeck A, et al. Differentiation-linked human papillomavirus types 6 and 11 transcription in genital condylomata revealed by in situ hybridization with Messenger-Specific RNA probes. Virology 1997; 172 331-340.

47. Komminoth P, Long AA. In-situ polymerase chain reaction. An overview of methods, applications and limitations of a new molecular technique. Virchows Arch B Cell Pathol Incl Mol Pathol 1993; 64: 67-73.

48. Liu J, Rose B, Huang X, et al. Comparative analysis of characteristics of women with cervical cancer in high versus low-incidence regions. Gynecol Oncol 2004; 94: 803-810.

49. Musiani M, Pasini P, Zerbini M, et al. Chemiluminescence: a sensitive detection system in in situ hybridization. Histol Histopathol 1998; 13: 243-248.

50. Sun J, Hu JB, Chen HL, et al. Expression of human papillomavirus type 16/18 in human cervical carcinomas by the quantum dot fluorescent in-situ hybridization. Zhonghua Bing Li Xue Za Zhi 2010; 39: 675-677.

51. Hesselink AT, van den Brule AJ, Brink AA, et al. Comparison of hybrid capture 2 with in situ hybridization for the detection of high-risk human papillomavirus in liquid-based cervical samples. Cancer 2004; 102: 11-18.

52. Kerstens HM, Poddighe PJ, Hanselaar AG. A novel in situ hybridization signal amplification method based on the deposition of biotinylated tyramine. J Histochem Cytochem 1995; 43: 347-352.

53. National Comprehensive Cancer Network. NCCN Clinical practice guidelines in oncology. Head and Neck Cancers.
Available at http://www.nccn.org/professionals/physician_gls/ pdf/head-and-neck.pdf. Date of access: 29.11.2013.

54. Feller L, Khammissa RA, Wood NH, et al. HPV-associated oral warts. SADJ 2011; 66: 82-85.

55. Padayachee A. Human papilomavirus (HPV) types 2 and 57 in oral verrucae demonstrated by in situ hybridization. J Oral Pathol Med 1994; 23: 413-417.

56. Eversole LR, Laipis PJ, Merrell P, et al. Demonstration of human papillomavirus DNA in oral condiloma acuminatum. J Oral Pathol 1987; 16: 266-272.

57. Tominaga S, Fukushima K, Nishizaki K, et al. Presence of Human papillomavirus Type of in Tonsillar Codyloma Acuminatum and Clinically Normal Tonsillar mucosa. Jpn J Clin Oncology 1996; 26: 393-397.

58. Sand L, Jalouli J, Larsson PA, et al. Human papilloma viruses in oral lesions. Anticancer Res 2000; 20: 1183-1188.

59. Saghravanian N, Ghazvini K, Babakoohi S, et al. Low prevalence of high risk genotypes of human papilloma virus in normal oral mucosa, oral leukoplakia and verrucous carcinoma. Acta Odontol Scand 2011; 69: 406-409.

60. Miller CS, Dean KW. Human Papilloma Virus expression in oral mucosa, premalignant conditions and squamous cell carcinoma. A retrospective review of the literature. Oral Surg Oral Med Oral Path 1996; 82: 57-68.

61. Kashima HK, Kutcher M, Kessis T, et al. Human papillomavirus in squamous cell carcinoma, leukoplakia, lichen planus, and clinically normal epithelium of the oral cavity. Ann Otol Rhinol Laryngol 1990; 99: 55-61.

62. Pfister H, Hettich I, Runne U, et al. Characterization of human papillomavirus type 13 from focal epithelial hyperplasia Heck lesions. J Virol 1983; 47: 363-366.

63. Padayachee A, Van Wyk CW. Human papillomavirus (HPV) DNA in focal epithelial hyperplasia by in situ hybridization. J Oral Pathol Med 1991; 20: 210-214.

64. Henke RP, Guèrin-Reverchon I, Milde-Langosch K, et al. In situ detection of human papillomavirus Types 13 and 32 in focal epithelial hyperplasia of the oral mucosa. J Oral Pathol Med 1989; 18: 419-421.

65. Jontell M, Watts S, Wallström M, et al. Human papilloma virus in erosive oral lichen planus. J Oral Pathol Med 1990; 19: $273-277$

66. Silverman DA, Pitman MJ. Current diagnostic and management trends for recurrent respiratory papillomatosis. Curr Opin Otolaryngol Head Neck Surg 2004; 12: 532-537.

67. Manjarrez ME, Ocadiz R, Valle L, et al. Detection of human papillomavirus and relevant tumor suppressors and oncoproteins in laryngeal tumors. Clin Cancer Res 2006; 12: 69466951.

68. Aaltonen LM, Partanen J, Auvinen E, et al. HLA-DQ alleles and human papillomavirus DNA in adult-onset laryngeal papillomatosis. J Infect Dis 1999; 179: 682-685.

69. Piva MR, Santos Tde S, Martins Filho PR, et al. Inverted papilloma (Schneiderian papilloma) with involvement of the oral cavity: report of an unusual case. An Bras Dermatol 2011; 86: 779-783.

70. Syrjänen K, Syrjänen S. Solitary bronchial squamous cell papilloma - another human papillomavirus (HPV)-associated benign tumor: systematic review and meta-analysis. Contemp Oncol 2013; 17: 427-434

71. Hasegawa M, Deng Z, Maeda H, et al. Human papillomavirus load and physical status in sinonasal inverted papilloma and squamous cell carcinoma. Rhinology 2012; 50: 87-94.

72. Kraft M, Simmen D, Casas R, et al. Significance of human papillomavirus in sinonasal papillomas. J Laryngol Otol 2001; 115: 709-714

73. Hwang CF, Huang CC, Chien CY, et al. Human papillomavirus infection in oral papillary and verrucous lesions is a prognostic indicator of malignant transformation. Cancer Epidemiol 2012; 36: e122-127. 
74. Chuang AY, Chuang TC, Chang S, et al. Presence of HPV DNA in convalescent salivary rinses is an adverse prognostic marker in head and neck squamous cell carcinoma. Oral Oncol 2008; 44: 915-919.

75. Elamin F, Steingrimsdottir H, Wanakulasuriya S, et al. Prevalence of human papillomavirus infection in premalignant and malignant lesions of the oral cavity in U.K. subjects: a novel method of detection. Oral Oncology 1998; 34: 191-197.

76. Premoli-De-Percoco G, Ramirez JL. High-risk human papilloma virus in Oral squamous carcinoma: evidence of risk factors in a Venezuelan rural population. Preliminary report. J Oral Pathol 2001; 30: 355-361.

77. Ostwald C, Müller P, Barten M, et al. Human papillomavirus DNA in oral squamous cell carcinomas and normal mucosa. J Oral Pathol Med 1994; 23: 220-225.

78. Balaram P, Nalinakumari KR, Abraham E, et al. Human papillomaviruses in 91 oral cancers from Indian betel quid chewers - high prevalence and multiplicity of infections. Int J Cancer 1995; 61: 450-454.

79. Mehanna H, Beech T, Nicholson T, et al. Prevalence of human papillomavirus in oropharyngeal and nonoropharyngeal head and neck cancer - systematic review and meta-analysis of trends by time and region. Head Neck 2013; 35: 747-755.

80. Hansson BG, Rosenquist K, Antonsson A, et al. Strong association between infection with human papillomavirus and oral and oropharyngeal squamous cell carcinoma: a population-based case-control study in southern Sweden. Acta Otolaryngol 2005; 125: 1337-1344.

81. de Oliveira DE, Bacchi MM, Macarenco RS, et al. Human papillomavirus and Epstein-Barr virus infection, p53 expression, and cellular proliferation in laryngeal carcinoma. Am J Clin Pathol 2006; 126: 284-293.

82. Baumann JL, Cohen S, Evjen AN, et al. Human papillomavirus in early laryngeal carcinoma. Laryngoscope 2009; 119 1531-1537.

83. Morshed K. Association between human papillomavirus infection and laryngeal squamous cell carcinoma. J Med Virol 2010; 82: 1017-1023.

84. Bishop JA, Guo TW, Smith DF, et al. Human papillomavirus-related carcinomas of the sinonasal tract. Am J Surg Pathol 2013; 37: 185-192.

\section{Address for correspondence}

Katarzyna Bogusiak

Clinical Department of Maxillofacial Surgery

Medical University of Lodz, Poland

Kopcińskiego 22

90-153 Łódź

tel. +48426776788

e-mail: katarzyna.bogusiak@gmail.com 